\title{
Characteristics of patients with acute ST-segment elevation myocardial infarction treated with different combinations of antiaggregation therapy: experience from the Croatian branch of the ISACS-CT Registry
}

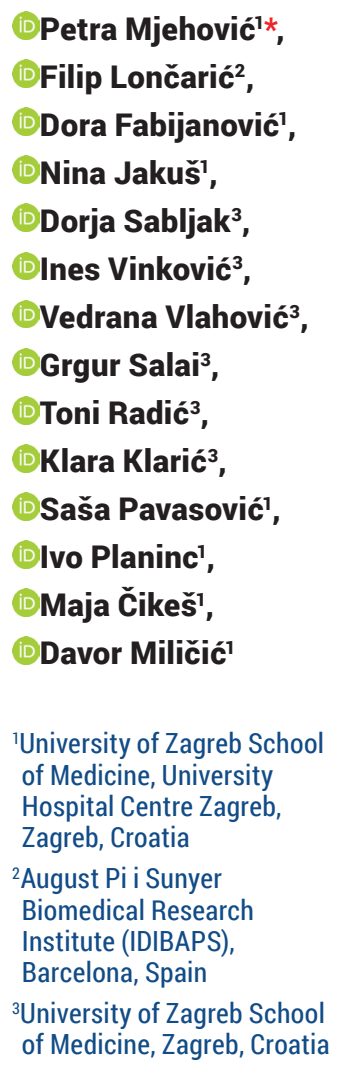

RECEIVED:

September 12, 2019

ACCEPTED:

September 16, 2019

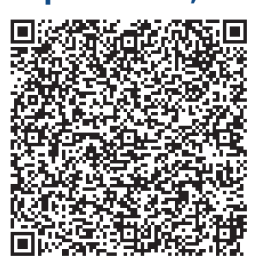

KEYWORDS: acute coronary syndrome, ST-elevation myocardial infarction, antiaggregation therapy, percutaneous coronary intervention.

CITATION: Cardiol Croat. 2019;14(9-10):211-2. | https://doi.org/10.15836/ccar2019.211

*ADDRESS FOR CORRESPONDENCE: Petra Mjehović, Klinički bolnički centar Zagreb, Kišpatićeva 12, HR-10000 Zagreb, Croatia. / Phone: +385-91-8970-556 / E-mail: petra.mjehovic@gmail.com

ORCID: Petra Mjehović, https://orcid.org/0000-0003-4908-4674 • Filip Lončarić, https://orcid.org/0000-0002-7865-1108 Dora Fabijanović, https://orcid.org/0000-0003-2633-3439 • Nina Jakuš, https://orcid.org/0000-0001-7304-1127 Dorja Sabljak, https://orcid.org/0000-0002-7785-5555 • Ines Vinković, https://orcid.org/0000-0003-1705-8295 Vedrana Vlahović, https://orcid.org/0000-0002-8021-4855 • Grgur Salai, https://orcid.org/0000-0002-7782-1646 Toni Radić, https://orcid.org/0000-0002-2695-3964 • Klara Klarić, https://orcid.org/0000-0002-4180-692X Saša Pavasović, https://orcid.org/0000-0002-3705-0226 • Ivo Planinc, https://orcid.org/0000-0003-0561-6704 Maja Čikeš, https://orcid.org/0000-0002-4772-5549• Davor Miličić, https://orcid.org/0000-0001-9101-1570

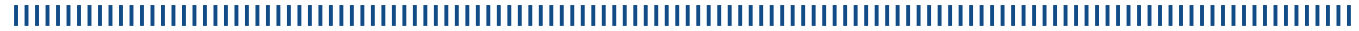

Background and Aim: The relevance of dual antiplatelet therapy (DAPT) in acute ST-segment elevation myocardial infarction (STEMI) is well-established (aspirin and P2Y12 inhibitors). ${ }^{1}$ The role of glycoprotein (GP) IIb/IIla inhibitors in clinical practice is not completely defined. Administration in the event of thrombotic complications is considered reasonable, although there is no evidence for routine use in primary percutaneous coronary intervention (pPCI). The aim was to analyze early outcomes of STEMI patients (pts) in the Croatian branch of the ISACS-CT (International Registry of Acute Coronary Syndromes in Transitional Countries) registry, depending on received antiaggregation therapy.

Patients and Methods: Data were gathered retrospectively from pts hospitalized between January 2012 to October 2017. The study included 2503 pts with acute coronary syndrome, from which 48.9\% ( $n=1224)$ were diagnosed with STEMI. The patients were divided into 4 groups depending on administered antiaggregation therapy.

Results: For 7.8\% ( $n=96)$ pts antiaggregation therapy data were missing, and 5.8\% ( $n=71)$ were not treated with DAPT. Remaining 1057 (86.4\%) pts were analyzed. Aspirin was administered in 95\% of pts in the first 24 hours. $41.9 \%(n=443)$ of pts were additionally treated with clopidogrel, $16.1 \%(n=170)$ with ticagrelor, 28.6\% ( $n=302$ ) with clopidogrel and eptifibatide, and 13.4\% ( $n=142)$ with ticagrelor and eptifibatide (Table 1). The groups did not differ in comorbidities, while pts receiving eptifibatide had lower systolic blood pressure on admission. Patients treated with eptifibatide were more frequently male, smokers, of younger age, had more thrombotic complications seen on coronary angiography (predominantly distal embolisation and "no-reflow" phenomenon) and lower in-hospital mortality. In a multivariable regression model adjusted for age, gender, hypertension, diabetes, and pPCI, increasing age (OR=1.1), diabetes (OR=1.9) and pPCI (OR=0.5) remained relevant to in-hospital mortality.

Conclusion: STEMI patients that are young, male and smokers are more frequently treated with eptifibatide, likely due to a higher burden of thrombotic complications. Unlike the choice of antiaggregation therapy, increasing age, diabetes and non-invasive management of STEMI were associated with in-hospital mortality.

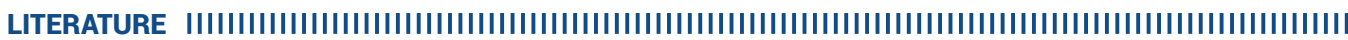

1. Ibanez B, James S, Agewall S, Antunes MJ, Bucciarelli-Ducci C, Bueno H, et al; ESC Scientific Document Group. 2017 ESC Guidelines for the management of acute myocardial infarction in patients presenting with ST-segment elevation: The Task Force for the management of acute myocardial infarction in patients presenting with ST-segment elevation of the European Society of Cardiology (ESC). Eur Heart J. 2018 Jan 7;39(2):119-177. https://doi.org/10.1093/eurheartj/ehx393 
TABLE 1. Patients' characteristics.

\begin{tabular}{|c|c|c|c|c|c|}
\hline & $\begin{array}{c}\text { ASAt } \\
\text { Clopidogrel } \\
(n=443)\end{array}$ & $\begin{array}{c}\text { ASAt } \\
\text { Ticagrelor } \\
(\mathrm{n}=170)\end{array}$ & $\begin{array}{c}\text { ASA+ Clopidogrel } \\
+ \text { Eptifibatide } \\
(n=302)\end{array}$ & $\begin{array}{c}\text { ASA + Ticagre- } \\
\text { lor + Eptifibati- } \\
\text { de ( } n=142)\end{array}$ & p-value \\
\hline Male gender, $\mathbf{n}(\%)$ & $296(66.8)$ & $112(65.9)$ & $224(74.2)$ & $110(77.5)$ & 0.020 \\
\hline Age (IQR) & $63(53,75)$ & $66(55,77)$ & $62(54,71)$ & $59(52,68)$ & 0.002 \\
\hline Hypertension, n (\%) & $294(68.9)$ & $119(73.0)$ & $199(66.6)$ & $91(64.1)$ & 0.348 \\
\hline Hypercholesterolemia, n (\%) & $179(44.8)$ & $68(43.0)$ & $150(51.2)$ & $76(54.3)$ & 0.085 \\
\hline Diabetes mellitus, n (\%) & $106(24.3)$ & $37(22.3)$ & $51(16.9)$ & $34(23.9)$ & 0.106 \\
\hline Chronic kidney disease, n (\%) & $32(9.3)$ & $10(6.1)$ & $23(8.0)$ & $7(5.0)$ & 0.344 \\
\hline Smoking, n (\%) & $221(55.4)$ & $87(58.8)$ & $179(61.9)$ & $96(69.6)$ & 0.025 \\
\hline HR median (IQR) & $80(70,92)$ & $80(71,94)$ & $80(70,92)$ & $78(66,92)$ & 0.318 \\
\hline SBP median (IQR) & $138(120,150)$ & $135(115,153)$ & $130(112,145)$ & $130(120,150)$ & 0.017 \\
\hline Creatinine (IQR) & $95(81,112)$ & $83(72,101)$ & $93(78,111)$ & $81(69,95)$ & $<0.001$ \\
\hline hsTnT max median (IQR) & $3.63(1.45,9.40)$ & $3.2(1.31,7.74)$ & $4.22(1.90,9.60)$ & $4.86(2.04,8.93)$ & 0.156 \\
\hline Platelets (IQR) & $219(188,262)$ & $229(189,265)$ & $231(187,266)$ & $231(192,258)$ & 0.704 \\
\hline LVEF median (IQR) & $50(40,55)$ & $45(40,52)$ & $45(40,55)$ & $45(40,55)$ & 0.007 \\
\hline pPCI, n (\%) & $338(77.0)$ & $152(89.4)$ & $294(97.7)$ & $139(97.9)$ & $<0.001$ \\
\hline $\begin{array}{l}\text { Coronary angiography - number } \\
\text { of lesions }>2, n(\%)\end{array}$ & $105(31.1)$ & $48(30.4)$ & $77(25.8)$ & $31(22.1)$ & 0.161 \\
\hline $\begin{array}{l}\mathrm{PCI} \text { - number of treated lesions } \\
>1, n(\%)\end{array}$ & $57(19.6)$ & $38(25.7)$ & $55(18.9)$ & $26(18.7)$ & 0.350 \\
\hline $\begin{array}{l}\text { Thrombotic complications, n } \\
\text { (\%) }\end{array}$ & $29(8.7)$ & $9(6.0)$ & $48(16.5)$ & $29(20.7)$ & $<0.001$ \\
\hline Distal coronary embolisation & $3(0.9)$ & $1(0.7)$ & $12(4.1)$ & $13(9.3)$ & \\
\hline "No-reflow" phenomenon & $10(3.0)$ & $3(2.0)$ & $11(3.8)$ & $5(3.6)$ & \\
\hline Other & $16(4.8)$ & $5(3.3)$ & $25(8.6)$ & $11(7.8)$ & \\
\hline In-hospital mortality, n (\%) & $33(7.4)$ & $14(8.2)$ & $9(3.0)$ & $5(3.5)$ & 0.020 \\
\hline
\end{tabular}

